\title{
Magnetostratigraphic evidence for post-depositional distortion of osmium isotopic records in pelagic clay and its implications for mineral flux estimates
}

\author{
Yoichi Usui ${ }^{*}$ (1) and Toshitsugu Yamazaki²
}

\begin{abstract}
Chemical stratigraphy is useful for dating deep-sea sediments, which sometimes lack radiometric or biostratigraphic constraints. Oxic pelagic clay contains Fe-Mn oxyhydroxides that can retain seawater ${ }^{187} \mathrm{Os} /{ }^{188} \mathrm{Os}$ values, and its age can be estimated by fitting the isotopic ratios to the seawater ${ }^{187} \mathrm{Os} /{ }^{188} \mathrm{Os}$ curve. On the other hand, the stability of Fe-Mn oxyhydroxides is sensitive to redox change, and it is not clear whether the original ${ }^{187} \mathrm{Os} /{ }^{188} \mathrm{Os}$ values are always preserved in sediments. However, due to the lack of independent age constraints, the reliability of ${ }^{187} \mathrm{Os} /{ }^{188} \mathrm{Os}$ ages of pelagic clay has never been tested. Here we report inconsistency between magnetostratigraphic and ${ }^{187} \mathrm{Os} /{ }^{188} \mathrm{Os}$ ages in pelagic clay around Minamitorishima Island. In a $\sim 5-\mathrm{m}$-thick interval, previous studies correlated ${ }^{187} \mathrm{Os} /{ }^{188} \mathrm{Os}$ data to a brief ( $<1$ million years) isotopic excursion in the late Eocene. Paleomagnetic measurements revealed at least 12 polarity zones in the interval, indicating a > 2.9-6.9 million years duration. Quartz and feldspars content showed that while the paleomagnetic chronology gives reasonable eolian flux estimates, the ${ }^{187} \mathrm{Os} /{ }^{188} \mathrm{Os}$ chronology leads to unrealistically high values. These results suggest that the low ${ }^{187} \mathrm{Os} /{ }^{188} \mathrm{Os}$ signal has diffused from an original thin layer to the current $\sim 5-\mathrm{m}$ interval, causing an underestimate of the deposition duration. The preservation of the polarity patterns indicates that a mechanical mixing such as bioturbation cannot be the main process for the diffusion, so diagenetic redistribution of Fe-Mn oxyhydroxides and associated Os may be responsible. The paleomagnetic chronology presented here also demands reconsiderations of the timing, accumulation rate, and origins of the high content of rare-earth elements and yttrium in pelagic clay around Minamitorishima Island.
\end{abstract}

Keywords: Deep-sea sediments, Chronology, Eocene, Oligocene, Diagenesis, Bioturbation, Eolian dust, Rare-earth elements

\section{Introduction}

Hydrogenous Os isotopic ratios are useful chronological markers for unfossiliferous pelagic clay, especially around the Eocene-Oligocene boundary (e.g., Peucker-Ehrenbrink and Ravizza 2012). Oxic pelagic

\footnotetext{
*Correspondence: yoichi@jamstec.go.jp

${ }^{1}$ Volcanoes and Earth's Interior Research Center, Research Institute for Marine Geodynamics, Japan Agency for Marine-Earth Science and Technology, 2-15 Natushima-cho, Yokosuka 237-0061, Japan Full list of author information is available at the end of the article
}

clay contains $\mathrm{Fe}-\mathrm{Mn}$ oxyhydroxides precipitated from seawater (e.g., Uramoto et al. 2019). These oxyhydroxides capture osmium in seawater (Koide et al. 1991) and record the ${ }^{187} \mathrm{Os} /{ }^{188} \mathrm{Os}$ at the time of deposition. In the late Eocene, seawater ${ }^{187} \mathrm{Os} /{ }^{188} \mathrm{Os}$ show a large excursion to unradiogenic (low ${ }^{187} \mathrm{Os} /{ }^{188} \mathrm{Os}$ ) values (Ravizza and Peucker-Ehrenbrink 2003). This excursion was identified not only in pelagic clay (Pegram and Turekian 1999) and ferromanganese crusts (Klemm et al. 2005; Nielsen et al. 2009), but also in biogenic sediments with highresolution biostratigraphic and magnetostratigraphic 
age models (Ravizza and Peucker-Ehrenbrink 2003; Dalai et al. 2006). The age of the ${ }^{187} \mathrm{Os} /{ }^{188} \mathrm{Os}$ minimum was estimated to be $34.5 \pm 0.1 \mathrm{Ma}$ (Dalai et al. 2006). It has also been proposed that dating of pelagic clay with $\sim 0.1$ million-year (Myr) resolution is possible by matching the shape of the excursion (Dalai et al. 2006; Nozaki et al. 2019; Ohta et al. 2020). However, the reliability of this method critically depends on the assumptions that $\mathrm{Fe}-$ Mn oxyhydroxides are hydrogenous and have been stable since deposition (e.g., Peucker-Ehrenbrink and Ravizza 2000).

Processes such as bioturbation and diagenesis can diffuse $\mathrm{Fe}-\mathrm{Mn}$ oxyhydroxides either mechanically or chemically, so they can potentially distort the Os isotopic records. Bioturbation appears to be ubiquitous, even in pelagic clay of oligotrophic oceans (e.g., Rutledge et al. 1995; Expedition 329 Scientists 2011). Detailed geochemical studies of sediments and $\mathrm{Fe}-\mathrm{Mn}$ nodules in the northeastern Pacific suggested that deep-sea redox conditions may have varied in response to surface productivity changes even if it is oxic at present (Mewes et al. 2014; Wegorzewski and Kuhn 2014). Diagenetic Fe-Mn micronodules were reported from surface clay in the western Pacific (Li et al. 2020). Abundant magnetite produced by magnetotactic bacteria was also found in oxic pelagic clay (Yamazaki and Shimono 2013; Shimono and Yamazaki 2016; Usui et al. 2017, 2019). These bacteria are thought to live near oxic/anoxic transition, suggesting the presence of reducing microenvironment (Yamazaki and Shimono 2013).

Because pelagic clay generally has a low sedimentation rate $(<1 \mathrm{~m} / \mathrm{Myr})$, post-depositional modifications would affect the reliability of ${ }^{187} \mathrm{Os} /{ }^{188} \mathrm{Os}$ stratigraphy. To date, however, no pelagic clay with ${ }^{187} \mathrm{Os} /{ }^{188}$ Os data has been accompanied by independent age constraints with sufficient resolution to confirm the stability of the isotopic records. In this study, we report the magnetostratigraphy within the putative late Eocene ${ }^{187} \mathrm{Os} /{ }^{188} \mathrm{Os}$ excursion in pelagic clay around Minamitorishima Island. Flux estimates for eolian dust and fish debris are discussed to evaluate the different chronologies.

\section{Materials}

We studied pelagic clay recovered by a piston core MR14-E02 PC11 around Minamitorishima Island at $154^{\circ} 00.98^{\prime} \mathrm{E}, 22^{\circ} 59.02^{\prime} \mathrm{N}$, and $5,647 \mathrm{~m}$ water depth (Additional file 1). The core length was $13.12 \mathrm{~m}$. The sediments were brown to dark brown clay. There was a manganeserich layer at 4.12-4.33 m core depth. Lithological observation suggests it represents a hiatus. A ${ }^{187} \mathrm{Os} /{ }^{188} \mathrm{Os}$ excursion in this core was interpreted as the late Eocene excursion (Nozaki et al. 2019), as well as in a nearby core KR13-02 PC05 (Ohta et al. 2020). Geochemical and magnetic correlations confirmed that they are in the same stratigraphic position (Tanaka et al. 2020; Yamazaki et al. 2020).

In both cores, the ${ }^{187} \mathrm{Os} /{ }^{188}$ Os excursions roughly coincide with the high concentrations ( $>2000 \mathrm{ppm}$ ) of rareearth elements and yttrium (REY), labeled as the 1st REY peak (Iijima et al. 2016; Tanaka et al. 2020). REY in pelagic clay are mainly carried by fish debris consisting of biogenic apatite (Kashiwabara et al. 2014, 2018; Yasukawa et al. 2016), especially in this region (Takaya et al. 2018; Yasukawa et al. 2019). From these observations, Ohta et al. (2020) proposed that fish production increased significantly at $\sim 34.4 \mathrm{Ma}$ in response to the expansion of the Antarctic ice sheet (Katz et al. 2008).

\section{Methods}

\section{Paleomagnetism and rock magnetism}

Cubic samples were taken from the archive halves of the core by pushing $7-\mathrm{cm}^{3}$ plastic cubes. The samples were taken continuously, and every other cube was used for this study, resulting in a resolution of $\sim 4.5 \mathrm{~cm}$. The interval $1.2-1.7 \mathrm{~m}$ was disturbed by coring, and the interval 3.9-4.9 m was very stiff due to Mn enrichment. Consequently, we did not sample these intervals. A hiatus was estimated at $\sim 4.2 \mathrm{~m}$ based on lithological changes (Nozaki et al. 2019). Progressive AF demagnetizations of natural remanence were conducted using a cryogenic magnetometer $2 \mathrm{G}$ Enterprises 760 at the Center for Advanced Marine Core Research (CMCR), Kochi University. The results were analyzed by principal component analysis to isolate characteristic remanence (Kirschvink 1980). We use results with maximum angular deviation (MAD) smaller than $15^{\circ}$ for further analyses. Because the core was not azimuthally oriented, we first estimated polarity patterns by near $180^{\circ}$ changes in relative declination and inclination sign. For intervals with possible polarity changes, we calculated virtual geomagnetic pole (VGP). We used the VGP latitude, which combines information from declination and inclination, for further interpretation. Chronostratigraphy was estimated by comparing the polarity patterns with the geomagnetic polarity time scale (GPTS) in Geological Time Scale 2012 (Ogg 2012).

Magnetic properties of the samples were examined to help paleomagnetic interpretation. We measured the ratio of anhysteretic remanence (ARM) susceptibility $\left(\kappa_{\text {ARM }}\right)$ to saturation isothermal remanence (SIRM) and $S$ ratios (Bloemendal et al. 1992). In the Minamitorishima region, $\kappa_{\mathrm{ARM}} / \mathrm{SIRM}$ reflects the abundance of biogenic magnetite relative to terrigenous magnetic minerals (Usui et al. 2017, 2019; Yamazaki et al. 2020). After paleomagnetic measurements, ARMs were imparted with a 0.1 $\mathrm{mT}$ DC field and $80 \mathrm{mT}$ peak AF field using the cryogenic 
magnetometer at CMCR. IRMs were imparted with $2.5 \mathrm{~T}$ field using a pulse magnetizer magnetic measurements model MMPM-10 at Atmosphere and Ocean Research Institute, the University of Tokyo. $S$ ratios measure the relative abundance of minerals with contrasting coercivity. SIRM measurements were followed by IRMs imparted by back fields of -0.1 and -0.3 T. $S$ ratios $\left(S_{-0.1}\right.$ and $\left.S_{-0.3}\right)$ were calculated following the definition of Bloemendal et al. (1992). In pelagic sediments, $S_{-0.1}$ and $S_{-0.3}$ often reflect the relative abundance of biogenic magnetite to abiotic (eolian) magnetic minerals, and ferromagnetic minerals to antiferromagnetic minerals (e.g., hematite), respectively (e.g., Bloemendal et al. 1992; Yamazaki 2009; Usui et al. 2017).

\section{Quartz and feldspar content}

To quantify eolian dust content, we separated quartz and feldspars using the sodium pyrosulfate $\left(\mathrm{Na}_{2} \mathrm{~S}_{2} \mathrm{O}_{7}\right)$ fusion method (Kiely and Jackson 1964; Syers et al. 1968; Clayton et al. 1972; Blatt et al. 1982; Stevens 1991; Usui et al. 2018). Dry samples of $\sim 1 \mathrm{~g}$ were first treated with citratebicarbonate-dithionite (CBD) to remove poorly crystalline Fe-Mn oxyhydroxides (Rea and Janecek 1981). The residues were washed with purified water, freeze-dried, weighed, and treated with acetic acid overnight, which has been assumed to remove carbonate and apatite. The oxyhydroxides-free residues were washed, freezedried, weighed, and fused with $\mathrm{Na}_{2} \mathrm{~S}_{2} \mathrm{O}_{7}$ at $460{ }^{\circ} \mathrm{C}$, which decompose sheet silicates. The fusions were treated with
$3 \mathrm{~N} \mathrm{HCl}$ and washed with purified water to remove solidified potassium pyrosulfate and relict clays. Then, the residues were heated to $50^{\circ} \mathrm{C}$ in $1 \mathrm{M} \mathrm{NaOH}$ overnight to remove relict clays.

\section{Results}

\section{Rock magnetism}

Rock magnetic properties showed smooth variations (Fig. 1). $\kappa_{\text {ARM }} /$ SIRM were $\sim 1 \mathrm{~mm} /$ A down to $\sim 6 \mathrm{~m}$. They increased to $>2.0 \mathrm{~mm} / \mathrm{A}$ below $\sim 7 \mathrm{~m}$ into the 1st REY peak, indicating dominance of biogenic magnetite over terrigenous magnetic minerals. These behaviors are consistent with those of nearby cores (Usui et al. 2017; Yamazaki et al. 2020). S ratios were high, indicating limited contribution from antiferromagnetic minerals. $S_{-0.1}$ were close to 1 between $\sim 6$ and $12 \mathrm{~m}$ (Fig. 1b), indicating dominance of low-coercivity minerals such as biogenic magnetite. $S_{-03}$ were slightly lower below $\sim 12 \mathrm{~m}$ (chemostratigraphic Unit III of Tanaka et al. 2020), suggesting an increase in antiferromagnetic minerals such as hematite.

\section{Paleomagnetism}

Clear polarity patterns were obtained at limited intervals (Fig. 1c, d). Top $\sim 8 \mathrm{~m}$ was characterized by stable declination dominated by apparent normal polarity (positive inclination; Fig. 1d). Considering the proposed chronology $(\sim 2 \mathrm{Ma}$ at $0.01 \mathrm{~m}$ and $\sim 34 \mathrm{Ma}$ at $\sim 7 \mathrm{~m}$; Nozaki et al. 2019), we interpreted that this
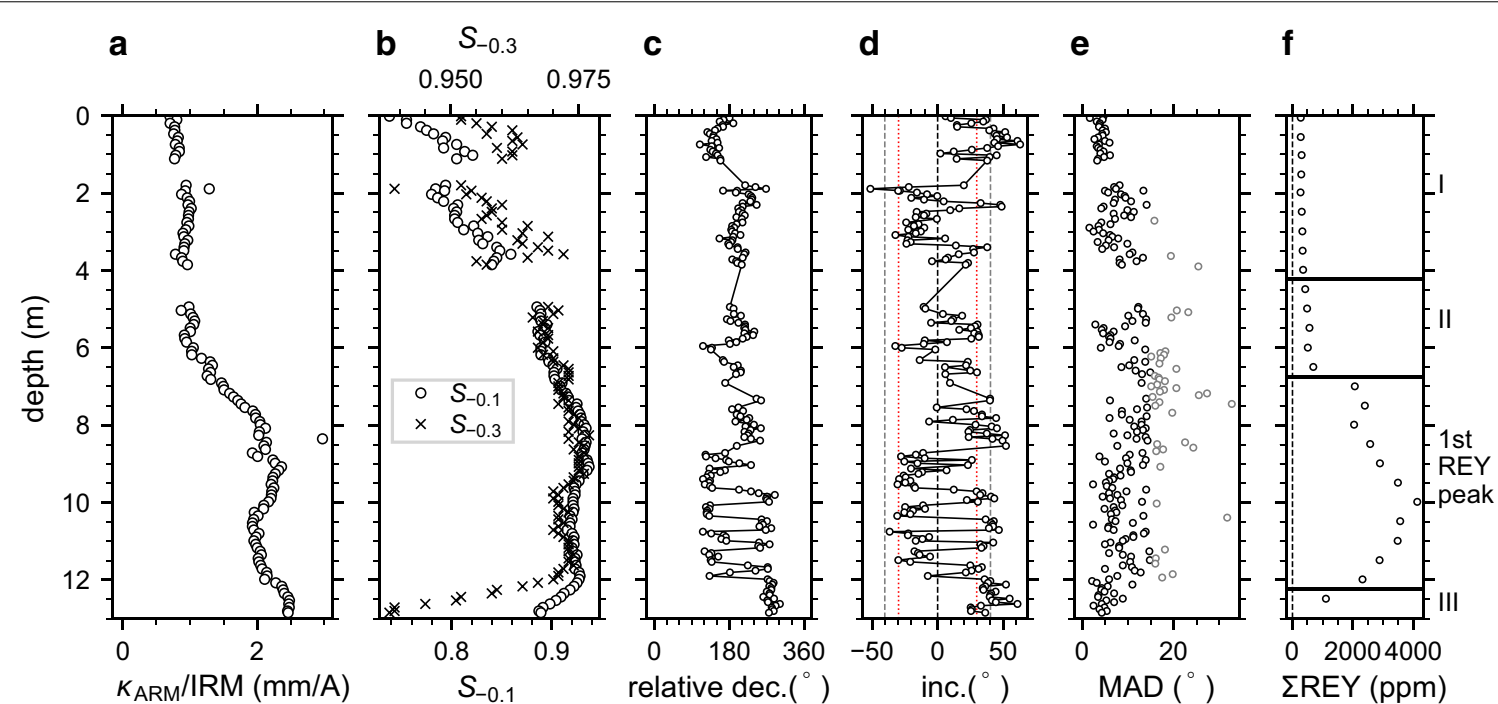

Fig. 1 Depth variations of rock magnetic and paleomagnetic results. a $K_{\text {ARM }} / S I R M$. b $S$ ratios. Open circles represent $S_{-0.1}$, and crosses represent $S_{-0.3}$. c Relative declination. The core was not azimuthally oriented with respect to the geographic coordinates. $\mathbf{d}$ Inclination. Vertical lines show expected inclinations for geocentric axial dipole. Gray dashed lines are for $24^{\circ}$ latitude (present day), and red dotted lines are for $16^{\circ}$ latitude ( 35 Ma; Matthews et al., 2016). e Maximum angular deviation (MAD). Gray symbols show data with MAD $>15^{\circ}$, which are not plotted in $\mathbf{c}$ and $\mathbf{d}$. $\mathbf{f}$ Variation of total REY content (lijima et al., 2016). On the right are chemostratigraphic Units of Tanaka et al. (2020) 
normal polarity is not an original signal but reflect viscous overprint and cancellation of a dual polarity due to slow sedimentation. This interpretation is partly supported by the presence of normal polarity overprints in samples with characteristic remanence with negative inclinations (Additional file $2 \mathrm{~b}$ ). Consequently, we did not assign polarity above $8 \mathrm{~m}$. Below $8 \mathrm{~m}$, changes in inclination signs together with near $180^{\circ}$ changes in relative declination were observed (Fig. 1c, d). The absolute inclination is slightly larger in samples with positive inclinations. We interpreted this is also due to incomplete removal of the viscous overprint.

We calculated the VGP positions for intervals below $8 \mathrm{~m}$. To calculate the VGP, we corrected the core orientation assuming that the mean of the relative declinations of the samples with negative inclinations correspond to geographic south. The VGP latitude showed swings between $+50^{\circ}$ and $-60^{\circ}$ (Fig. 2). The plate motion after sedimentation and the incomplete removal of viscous overprint would reduce the quality of the VGP data. We simply assign normal and reversed polarities to the intervals with positive and negative VGP latitudes, respectively (Fig. 2; Additional file 3). Above $\sim 8.5 \mathrm{~m}$, the VGP latitude showed small oscillation around $0^{\circ}$. This is unlikely to be the geomagnetic signal; rather, it mainly reflects the anomalous

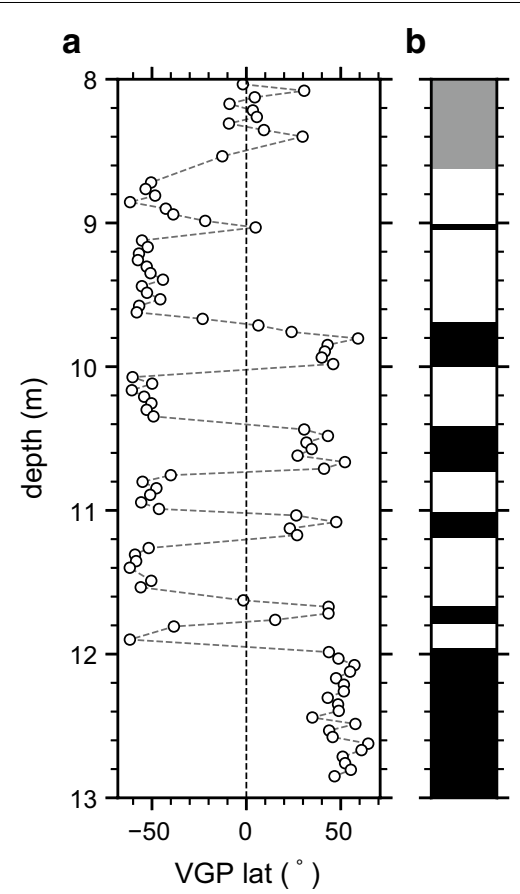

Fig. 2 a Depth variation of VGP latitude. $\mathbf{b}$ Interpreted polarity. Black represents normal polarity, white represents reversed polarity, and gray represents an interval of uncertain polarity (see text for discussion) declination (Fig. 1c). We did not interpret the polarity in this interval. The core showed 12 polarity zones with comparable lengths between 8.5 and $13 \mathrm{~m}$.

\section{Quartz and feldspars content}

The CBD treatment reduced the sample weight by $10-20 \%$ (Fig. 3a). This can be considered as approximated weight fractions of $\mathrm{Fe}-\mathrm{Mn}$ oxyhydroxides. The weight change was $\sim 10 \%$ at the top, gradually increased with depth to $\sim 15-20 \%$ towards $\sim 6 \mathrm{~m}$.

Acetic acid treatment further reduced the weight; the change was largest in 7-12 $\mathrm{m}$ where REY concentrations were high. This is consistent with the interpretation that fish debris carries REY (Iijima et al. 2016; Ohta et al. 2020). However, the change was at most $\sim 5 \%$ of the original weight. On the other hand, there is a strong linear relationship between $\mathrm{P}_{2} \mathrm{O}_{5}$ and REY content in sediments around Minamitorishima Island (Iijima et al. 2016; Takaya et al. 2018), suggesting the fraction of fish debris is nearly proportional to REY content. Using data from KR13-02 PC05 (Ohta et al. 2020), we can estimate that MR14-E02 PC11 clay (REY content up to $4000 \mathrm{ppm}$ ) contains up to $\sim 20 \mathrm{wt} . \%$ of fish debris. It is thus likely that acetic acid treatment does not remove biogenic apatite effectively.

$\mathrm{Na}_{2} \mathrm{~S}_{2} \mathrm{O}_{7}$ fusion further reduced the sample weight to $\sim 15-30$ wt.\% of the original weight (Fig. 3b). We consider these weights as the quartz and feldspars content. The highest content was from the top of the core. Below $7 \mathrm{~m}$, it was $\sim 15 \mathrm{wt} . \%$. Note that these numbers are

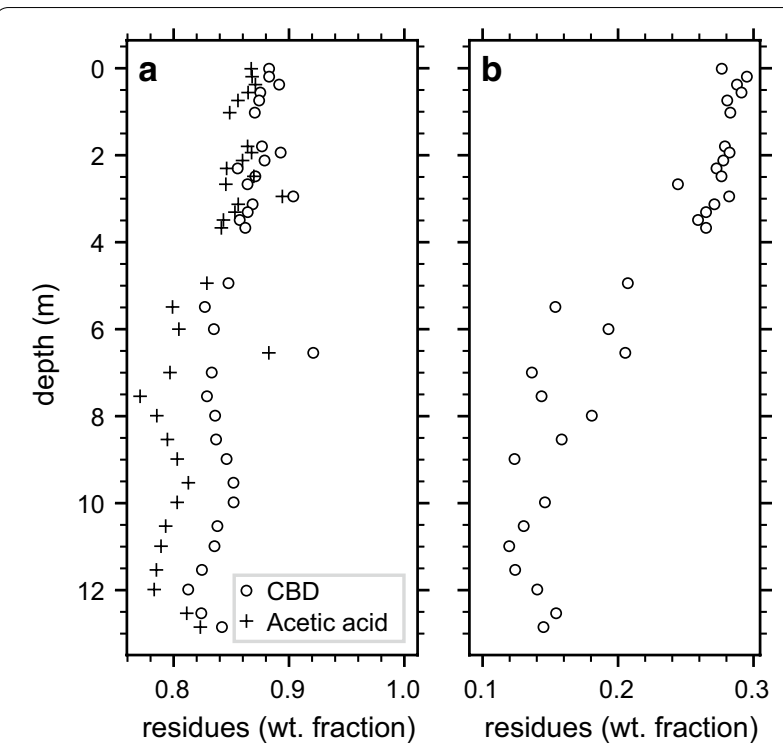

Fig. 3 Chemical digestion results. a Weight fraction of residue after CBD treatment (open circles) and subsequent acetic acid treatment (crosses). b Weight fraction of residue after sodium pyrosulfate fusion 
affected by Fe-Mn oxyhydroxides and fish debris content; given $\sim 15$ wt.\% of $\mathrm{Fe}-\mathrm{Mn}$ oxyhydroxides and up to $20 \mathrm{wt} . \%$ of fish debris below $7 \mathrm{~m}$, the weight fraction of quartz and feldspar relative to total silicate may be $\sim 20$ below $7 \mathrm{~m}$ and $\sim 20-30 \mathrm{wt} . \%$ throughout the core.

\section{Discussion}

\section{Chronostratigraphy and eolian flux estimates}

Our paleomagnetic data show that there are at least 12 polarity zones in 8.5-13 m (Fig. 2). Rock magnetic properties change smoothly in this interval (Fig. 1a, b), so these polarity zones are likely to reflect the geomagnetic reversals rather than short-scale variations in overprint. ${ }^{187} \mathrm{Os} /{ }^{188}$ Os were as low as 0.3 in $7-12 \mathrm{~m}$, and previous interpretations correlated them to the late Eocene excursion (Nozaki et al. 2019). However, this interpretation would put the 7-12 m interval into a single chron of $\mathrm{C} 13 \mathrm{r}$ (Fig. 4), while individual reversed polarity zones are $<50 \mathrm{~cm}$ in the core (Fig. 2).

Because there are only ichthyoliths stratigraphy constraints for late Eocene-early Oligocene ages of the corresponding 1st REY peak in KR13-02 PC05 (Ohta et al. 2020), we cannot correlate the observed polarity zones with GPTS uniquely. Nonetheless, based on the ichthyoliths data and the low ${ }^{187} \mathrm{Os} /{ }^{188} \mathrm{Os}$, we infer that the late Eocene ${ }^{187} \mathrm{Os} /{ }^{188} \mathrm{Os}$ excursion $(\sim 34.5 \mathrm{Ma})$ is somewhere in the 7-12 $\mathrm{m}$ interval. With this inference, we can list possible correlations with GPTS (Additional File 3; Fig. 4). Here we assumed that the sedimentation was continuous, and all the major chrons are recorded. These assumptions lead to conservative estimates for the depositional duration. The deepest polarity transition
(11.96 m), which coincides with the beginning of the 1st REY peak, would be between 34.999 and $38.615 \mathrm{Ma}$, and the shallowest polarity transition $(9.01 \mathrm{~m})$, which is deeper than the end of the 1st REY peak $(7 \mathrm{~m})$, would be between 28.141 and $35.706 \mathrm{Ma}$. All of these magnetostratigraphic correlations indicate that the deposition of the 1st REY peak took much longer ( $>2.9-6.9 \mathrm{Myr}$ ) than the ${ }^{187} \mathrm{Os} /{ }^{188}$ Os ages $(<1 \mathrm{Myr}$; Nozaki et al. 2019; Ohta et al. 2020). The linear sedimentation rate between 9.01 and $11.96 \mathrm{~m}$ is estimated to be $0.43-1.02 \mathrm{~m} / \mathrm{Myr}$, depending on the correlation to GPTS (Additional File 3). They are much smaller than the sedimentation rate estimate for the 1st REY peak based on ${ }^{187} \mathrm{Os} /{ }^{188} \mathrm{Os}$ (Nozaki et al. 2019; Ohta et al. 2020), but similar to the sedimentation rate above the 1st REY peak (Fig. 4).

Inconsistency between the magnetostratigraphy and ${ }^{187} \mathrm{Os} /{ }^{188}$ Os ages can be compared in terms of the eolian flux. The chemical digestion results (Fig. 3) show that quartz and feldspars account for 10-20 wt.\% of the dry sediments of the 1 st REY peak. ${ }^{187} \mathrm{Os} /{ }^{188}$ Os suggest the sedimentation rate of $\sim 3.3 \mathrm{~m} / \mathrm{Myr}$ for the 1 st REY peak of MR14-E02 PC11 (Nozaki et al. 2019; Fig. 4). Using a typical dry bulk density of $500 \mathrm{~kg} / \mathrm{m}^{3}$ (Ohta et al. 2020), these numbers are converted to a quartz and feldspars flux of $\sim 165-330 \mathrm{~kg} / \mathrm{m}^{2} /$ Myr. Typically, quartz and feldspars account for 10-20 wt.\% of eolian dust (Blank et al. 1985; Leinen et al. 1994; Usui et al. 2018), which is broadly consistent with our estimate of $\sim 20-30 \mathrm{wt}$.\% of the silicate. These numbers indicate $>500 \mathrm{~kg} / \mathrm{m}^{2} / \mathrm{Myr}$ of eolian flux. This is comparable to the current flux to the Pacific at $\sim 16^{\circ} \mathrm{N}$ (Rea 1994), where Minamitorishima Island was at $35 \mathrm{Ma}$. However, multiple records from the North

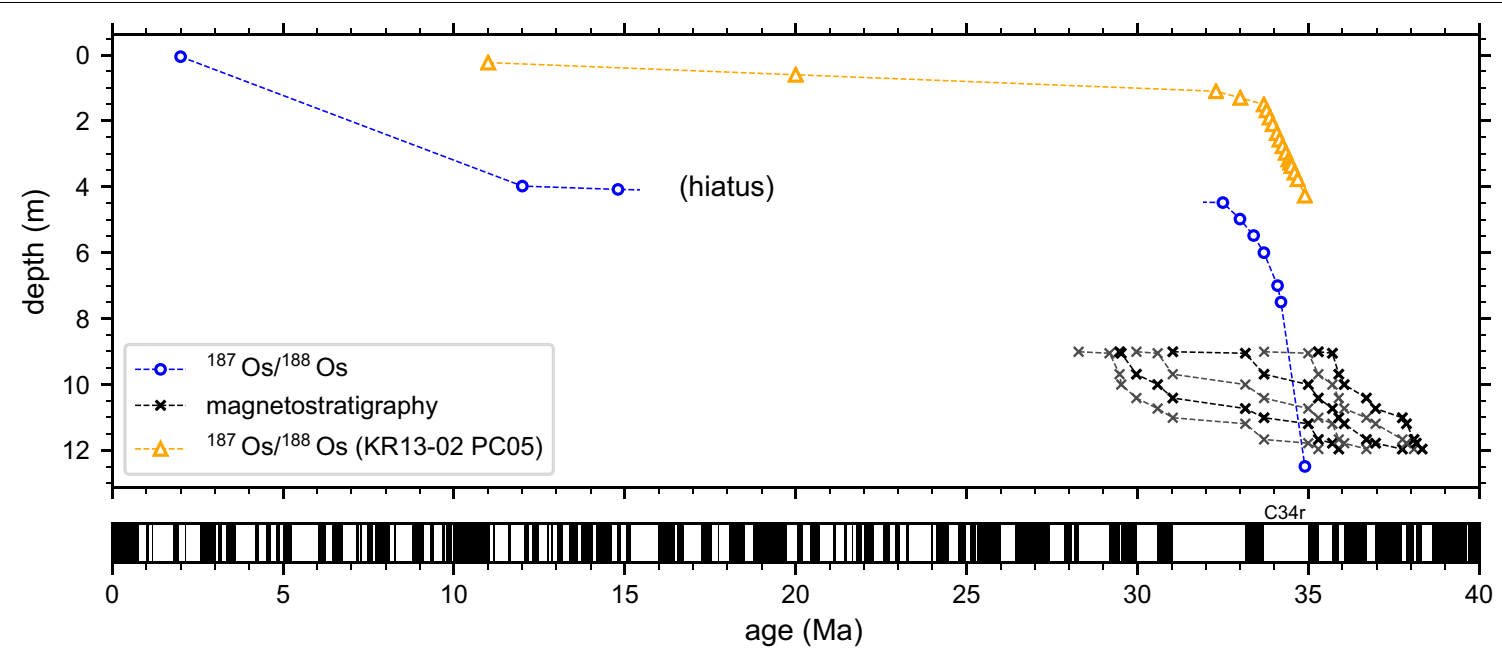

Fig. 4 Age-depth plot based on ${ }^{187} \mathrm{Os} /{ }^{188} \mathrm{Os}$ (blue circles; Nozaki et al. 2019) and paleomagnetism (gray crosses; Additional file 3: Table 1). Also shown is the ${ }^{187} \mathrm{Os} /{ }^{188} \mathrm{Os}$ ages of KR13-02 PC05 (orange triangles; Ohta et al. 2020). Shown at the bottom is the geomagnetic polarity time scale (Ogg 2012). Black represents normal polarity, white represents reversed polarity 
Pacific indicated that the eolian flux has increased by more than tenfold since $25 \mathrm{Ma}$ (e.g., Zhang et al. 2016). Only a few estimates exist for flux before $30 \mathrm{Ma}$, but it may be even smaller between 35 and $45 \mathrm{Ma}$ (Janecek and Rea 1983; Janecek 1985). Thus, the flux estimates based on the ${ }^{187} \mathrm{Os} /{ }^{188} \mathrm{Os}$ seem too large. In contrast, the magnetostratigraphy suggests sedimentation rates of 0.43-1.02 $\mathrm{m} / \mathrm{Myr}$ in the 1st REY peak (Fig. 4). They are converted to eolian flux estimates of $\sim 70-500 \mathrm{~kg} / \mathrm{m}^{2} /$ Myr. The lower end of the range is consistent with the evolution of the eolian flux in the North Pacific. Therefore, we argue that the ${ }^{187} \mathrm{Os} /{ }^{188} \mathrm{Os}$ ages overestimate the sedimentation rate of the 1st REY peak. We further consider that GPTS correlations which give slower sedimentation rates $(<0.5 \mathrm{~m} / \mathrm{Myr})$ are more plausible, implying that the deposition of the 1st REY took more than 6.5 Myr and completed later than $30 \mathrm{Ma}$ (Fig. 4).

\section{Possible mechanisms for the distortion of the osmium isotope record}

${ }^{187} \mathrm{Os} /{ }^{188} \mathrm{Os}$ are stably low throughout the 1 st REY peak, while the magnetostratigraphy predicts $<50 \mathrm{~cm}$ excursion (Fig. 5). Although processes such as extraterrestrial influx can modify the absolute ${ }^{187} \mathrm{Os} /{ }^{188}$ Os values, it is unlikely to eliminate only the excursion. Rather, the simplest explanation for the absence of a short excursion is post-depositional homogenization of ${ }^{187} \mathrm{Os} /{ }^{188} \mathrm{Os}$. Complete mechanical mixing by processes such as bioturbation over $\sim 5 \mathrm{~m}$ interval is unlikely, and they would also destroy the polarity records. So, we suspect chemical remobilization of $\mathrm{Fe}-\mathrm{Mn}$ oxyhydroxides as a cause of the homogeneous ${ }^{187} \mathrm{Os} /{ }^{188}$ Os. The 1 st REY peak represents enhanced flux of fish debris, which may have brought oxic-anoxic transition zone to shallow depths, promoting diagenetic movement of Mn (Mewes et al. 2014; Wegorzewski and Kuhn 2014).

A simple averaging of the seawater ${ }^{187} \mathrm{Os} /{ }^{188} \mathrm{Os}$ curve does not reproduce the absolute values observed in the core (Fig. 5b), suggesting additional processes were at work. We note three factors that help to resolve this problem, although these are not exhaustive and further quantitative research is required. First, Os influx to sediments may be variable, so homogenization involves taking weighted averages of the seawater curve. If the original Os deposition was sufficiently larger during the isotopic excursion than other period, then the ${ }^{187} \mathrm{Os} /{ }^{188} \mathrm{Os}$ after homogenization would be low, and Os content would be high. This is qualitatively consistent with the elevated Os content in the 1st REY peak of KR13-02 PC05 (Ohta et al. 2020); however, the Os content of MR14-E02 PC11

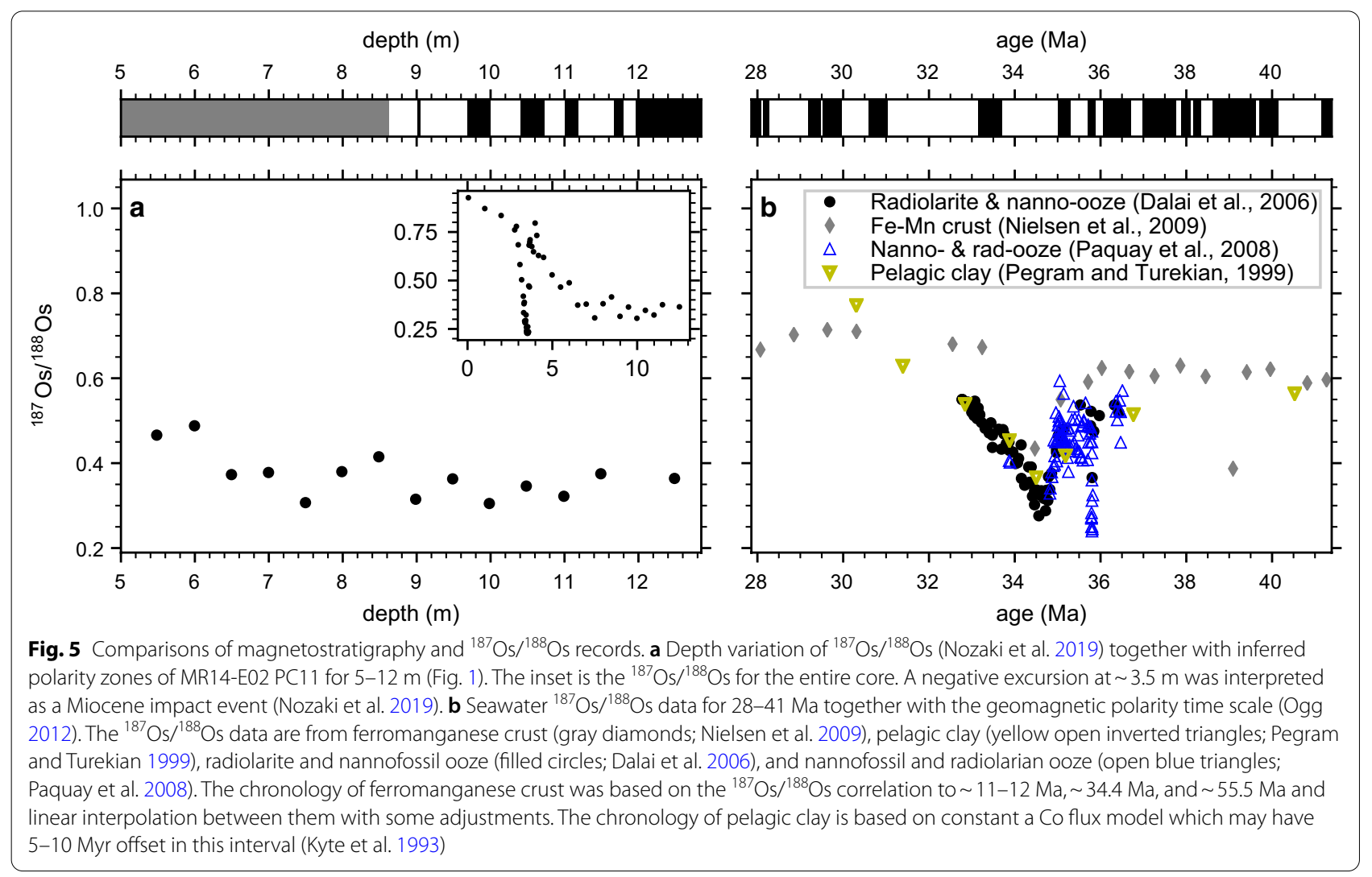


does not show a similar pattern (Nozaki et al. 2019), so the contribution of this factor may be limited. Second, ${ }^{187} \mathrm{Os} /{ }^{188} \mathrm{Os}$ may not be globally uniform. The ${ }^{187} \mathrm{Os} /{ }^{188} \mathrm{Os}$ minima in the excursion differ by 0.05 in two highresolution sites from the eastern equatorial Pacific (e.g., Peucker-Ehrenbrink and Ravizza 2012). This amount alone may be insufficient to explain the low ${ }^{187} \mathrm{Os} /{ }^{188} \mathrm{Os}$ in the 1st REY peak, but such heterogeneity should be considered. Finally, the ${ }^{187} \mathrm{Os} /{ }^{188} \mathrm{Os}$ of pelagic sediments may be contaminated by unradiogenic extraterrestrial and ultramafic components to yield lower values (e.g., Peucker-Ehrenbrink and Ravizza 2000). The ${ }^{187} \mathrm{Os} /{ }^{188} \mathrm{Os}$ in the Minamitorishima samples were analyzed using the Carius tube methods with reverse aqua regia (Shirey and Walker 1995), which would introduce extraterrestrial and ultramafic components, although the absolute abundance of these components are not known. Some argued that more diluted leaching solution $\left(0.15 \% \mathrm{H}_{2} \mathrm{O}_{2}\right)$ should be used to minimize the effect of extraterrestrial components (Turekian and Pegram 1997). Indeed, Nozaki et al. (2019) reported low ${ }^{187} \mathrm{Os} /{ }^{188} \mathrm{Os}$ due to an influx of extraterrestrial material from a Miocene impact event in the same core studied here. These factors may affect the ${ }^{187} \mathrm{Os} /{ }^{188} \mathrm{Os}$ dating outside the 1 st REY peak as well.

\section{Implication for the fish debris accumulation estimates}

The proposed revision of the chronology for the 1st REY peak affects the estimates of fish debris accumulation rates and the origin of the REY peaks. On the basis of the ${ }^{187} \mathrm{Os} /{ }^{188}$ Os ages, Ohta et al. (2020) estimated high fish debris accumulation rates of $>300 \mathrm{~kg} / \mathrm{m}^{2} / \mathrm{Myr}$ for the 1st REY peak in KR13-02 PC05. Our paleomagnetic data indicate that the deposition of the 1st REY peak may have taken $>10$ times longer. Therefore, we suggest that the maximum fish debris accumulation rate in the 1st REY peak was on the order of $10 \mathrm{~kg} / \mathrm{m}^{2} /$ Myr. Indeed, assuming a fish debris content of $20 \mathrm{wt} . \%$, the paleomagnetic linear sedimentation rates indicate that the peak fish debris accumulation rate for MR14-E02 PC11 was $43-101 \mathrm{~kg} / \mathrm{m}^{2} /$ Myr. The fact that the REY content shows a sharp maximum even within the 1st REY peak indicates significant temporal variation of the fish debris accumulation. Cenozoic fish debris accumulation rate in the central North Pacific can also be estimated using data from the core LL44-GPC3 (Kyte et al. 1993). Assuming that $\mathrm{P}_{2} \mathrm{O}_{5}$ is exclusively in fish debris at $30 \mathrm{wt}$.\% (Kon et al. 2014; Takaya et al. 2018), the estimated rate was mostly below $10 \mathrm{~kg} / \mathrm{m}^{2} / \mathrm{Myr}$ except for a peak at $\sim 66 \mathrm{Ma}$ and another smaller peak at $\sim 58 \mathrm{Ma}$ (see Additional file 4). Thus, the formation of the 1st REY peak around Minamitorishima Island still requires an explanation.

Ohta et al. (2020) suggested that the enhanced fish debris accumulation is related to the bottom water upwelling during the brief ice volume expansion at $\sim 34.15 \mathrm{Ma}$ (Katz et al. 2008). While upwelling is still a viable hypothesis, the paleomagnetic chronology indicates that the 1st REY peak reflects longer-term changes. The present paleomagnetic chronology cannot place unique ages (Additional file 3); a better chronology is needed to test the connections to specific paleoenvironmental events for the beginning and end of the 1st REY peak.

\section{Conclusion}

Magnetostratigraphy of MR14-E02 PC11 indicates > 2.96.9 Myr duration for the deposition of a layer where ${ }^{187} \mathrm{Os} /{ }^{188}$ Os was previously correlated to a $<1$ Myr excursion. Eolian flux estimates based on the direct measurements of quartz and feldspar content support that a duration longer than $6 \mathrm{Myr}$ is plausible. The inconsistency may have resulted from diagenetic redistribution of $\mathrm{Fe}-\mathrm{Mn}$ oxyhydroxides and associated Os under high biogenic flux. The revised chronology indicates that the fish debris accumulation rate in the interval was an order of magnitude lower than the previous estimates; nonetheless, it may be still significantly higher than other areas or time. The elevated fish debris flux is likely to be associated with long-term oceanographic changes rather than a single event. Our results indicate that high-resolution dating of pelagic clay using ${ }^{187} \mathrm{Os} /{ }^{188}$ Os should be conducted with care.

\section{Supplementary Information}

The online version contains supplementary material available at https://doi. org/10.1186/s40623-020-01338-4.

Additional file 1 Location and backtrack of the site. (Top) Location and backtrack path of Minamitorishima Island at 5 Myr intervals. The backtrack path was calculated using GPlates (Boyden et al. 2011) with the rotation model of Matthews et al. (2016). (Bottom) Detailed locations of the core sites.

Additional file $\mathbf{2}$ Representative orthogonal vector plots for the natural remanences. (a) Normal polarity sample. (b) Reversed polarity sample. (c-e) Samples whose polarities were indeterminate (see text for discussion). Solid circles show the horizontal projection, and open circles show the vertical projection. Colored markers show steps used for PCA analyses. Insets show decay of remanence intensity.

Additional file 3 GPTS correlation models. Possible correlations of paleomagnetic data to GPTS (Ogg, 2012).

Additional file $\mathbf{4}$ Cenozoic fish debris accumulation flux estimated for LL44-GPC3 in the central North Pacific. Fish debris accumulation rate estimates for LL44-GPC3. Data are from Kyte et al. (1993). P2O5 content was converted to fish debris content assuming that P2O5 is exclusively in fish debris at 30 wt.\%.

\section{Abbreviations}

Myr: Million-year; REY: Rare-earth elements and yttrium; ARM: Anhysteretic remanence; SIRM: Saturation isothermal remanence; IRM: Isothermal remanence; CMCR: The Center for Advanced Marine Core Research; GPTS: 
Geomagnetic polarity time scale; CBD: Citrate-bicarbonate-dithionite; VGP: Virtual geomagnetic pole.

\section{Acknowledgements}

We thank two anonymous reviewers for critical comments. We acknowledge Drs. Tatsuo Nozaki and Junichiro Ohta for sharing the compilation of seawater ${ }^{187} \mathrm{Os} /{ }^{188} \mathrm{Os}$ and stimulating discussion, Erika Tanaka and Kazuhide Mimura for information on the chemical composition of LL44-GPC3. YU thanks Aguri Irisawa for the help in the laboratory. Part of this study was performed under the cooperative research program of CMCR, Kochi University $15 \mathrm{~A} 022$ and 15B019. Paleoposition of the site was calculated using GPlates (Boyden et al. 2011) with the rotation model of Matthews et al. (2016). Additional file 1 was created using GMT5 (Wessel et al. 2013). Additional file 2 was created using MagePlot/P (ver. 1.1; Hatakeyama 2018).

\section{Author's contributions}

YU and TY contributed to conceptualization. YU conducted chemical digestion analyses, wrote the original draft. TY conducted magnetic analyses, reviewed and edited the draft. All authors read and approved the final manuscript.

\section{Funding}

This work was supported by JSPS KAKENHI Grant numbers JP17H01361 and JP17H04855.

\section{Availability of data and materials}

All data produced in this work are available in Zenodo repository (https://doi. org/10.5281/zenodo.4023918).

\section{Ethics approval and consent to participate}

Not applicable.

\section{Consent for publication}

Not applicable.

\section{Competing interests}

The authors declare that they have no competing interests.

\section{Author details}

${ }^{1}$ Volcanoes and Earth's Interior Research Center, Research Institute for Marine Geodynamics, Japan Agency for Marine-Earth Science and Technology, 2-15 Natushima-cho, Yokosuka 237-0061, Japan. ${ }^{2}$ Atmosphere and Ocean Research Institute, The University of Tokyo, 5-1-5 Kashiwanoha, Kashiwa, Chiba 277-8564, Japan.

Received: 15 September 2020 Accepted: 10 December 2020 Published online: 04 January 2021

\section{References}

Blank M, Leinen M, Prospero JM (1985) Major Asian aeolian inputs indicated by the mineralogy of aerosols and sediments in the western North Pacific. Nature 314:84-86. https://doi.org/10.1038/314084a0

Blatt H, Jones RL, Charles RG (1982) Separation of quartz and feldspars from mudrocks. J Sediment Petrol 52:660-662. https://doi.org/10.2110/ jsr.52.660

Bloemendal J, King JW, Hall FR, Doh SJ (1992) Rock magnetism of Late Neogene and Pleistocene deep-sea sediments: relationship to sediment source, diagenetic processes, and sediment lithology. J Geophys Res Solid Earth 97(B4):4361-4375. https://doi.org/10.1029/91JB03068

Boyden JA, Müller RD, Gurnis M, Torsvik TH, Clark JA, Turner M, Ivey-Law H, Watson RJ, Cannon JS (2011) Next-generation plate-tectonic reconstructions using GPlates. In: Keller GR, Baru C (eds) Geoinformatics: cyberinfrastructure for the solid earth sciences. Cambridge University Press, Cambridge, pp 95-114

Clayton RN, Rex RW, Syers JK, Jackson ML (1972) Oxygen isotope abundance in quartz from Pacific pelagic sediments. J Geophys Res 77:3907-3915

Dalai TK, Ravizza GE, Peucker-Ehrenbrink B (2006) The Late Eocene 1870s/1880s excursion: chemostratigraphy, cosmic dust flux and the
Early Oligocene glaciation. Earth Planet Sci Lett 241:477-492. https://doi. org/10.1016/j.epsl.2005.11.035

Expedition 329 Scientists (2011) Site U1365. In: D'Hondt S, Inagaki F, Zarikian CA, Scientists E 329 Proc. IODP, 329. Integrated Ocean Drilling Program Management International, Inc., Tokyo

Hatakeyama T (2018) Online plotting applications for paleomagnetic and rock magnetic data. Earth Planets Space 70:139. https://doi.org/10.1186/s4062 3-018-0906-5

lijima K, Yasukawa K, Fujinaga K, Nakamura K, Machida S, Takaya Y, Ohta J, Haraguchi S, Nishio Y, Usui Y, Nozaki T, Yamazaki T, Ichiyama Y, Ijiri A, Inagaki F, Machiyama H, Suzuki K, Kato Y (2016) Discovery of extremely REY-rich mud in the western North Pacific Ocean. Geochem J 50:557-573. https:// doi.org/10.2343/geochemj.2.0431

Janecek TR (1985) 26. Eolian sedimentation in the northwest Pacific Ocean: a preliminary examination of the data from Deep Sea Drilling Project Sites 576 and 578. In: Ross Heath G, Burckle LH, et al. (eds) Initial Reports of the Deep Sea Drilling Project, 86. U.S. Government Printing Office, Washington, pp 589-603

Janecek TR, Rea DK (1983) Eolian deposition in the northeast Pacific Ocean: cenozoic history of atmospheric circulation. GSA Bull 94:730-738. https:// doi.org/10.1130/0016-7606(1983)94\%3c730:editnp\%3e2.0.co;2

Kashiwabara T, Toda R, Fujinaga K, Honma T, Takahashi Y, Kato Y (2014) Determination of host phase of lanthanum in deep-sea REY-rich mud by XAFS and $\mu$-XRF using high-energy synchrotron radiation. Chem Lett 43:199-200. https://doi.org/10.1246/cl.130853

Kashiwabara T, Toda R, Nakamura K, Yasukawa K, Fujinaga K, Kubo S, Nozaki T, Takahashi Y, Suzuki K, Kato Y (2018) Synchrotron X-ray spectroscopic perspective on the formation mechanism of REY-rich muds in the Pacific Ocean. Geochim Cosmochim Acta 240:274-292. https://doi. org/10.1016/J.GCA.2018.08.013

Katz ME, Miller KG, Wright JD, Wade BS, Browning JV, Cramer BS, Rosenthal Y (2008) Stepwise transition from the Eocene greenhouse to the Oligocene icehouse. Nat Geosci 1:329-334. https://doi.org/10.1038/ngeo179

Kiely PV, Jackson ML (1964) Selective dissolution of micas from potassium feldspars by sodium pyrosulfate fusion of soils and sediments. Am Mineralog J Earth Planet Mater 49(11-12):1648-1659

Klemm V, Levasseur S, Frank M, Hein JR, Halliday AN (2005) Osmium isotope stratigraphy of a marine ferromanganese crust. Earth Planet Sci Lett 238:42-48. https://doi.org/10.1016/j.epsl.2005.07.016

Koide M, Goldberg ED, Niemeyer S, Gerlach D, Hodge V, Bertine KK, Padova A (1991) Osmium in marine sediments. Geochim Cosmochim Acta 55:1641-1648. https://doi.org/10.1016/0016-7037(91)90135-R

Kon Y, Hoshino M, Sanematsu K, Morita S, Tsunematsu M, Okamoto N, Yano N, Tanaka M, Takagi T (2014) Geochemical characteristics of apatite in heavy REE-rich deep-sea mud from Minami-Torishima Area, Southeastern Japan. Resour Geol 64:47-57. https://doi.org/10.1111/rge.12026

Kyte FT, Leinen M, Ross Heath G, Zhou L (1993) Cenozoic sedimentation history of the central North Pacific: inferences from the elemental geochemistry of core LL44-GPC3. Geochim Cosmochim Acta 57:1719-1740. https ://doi.org/10.1016/0016-7037(93)90109-A

Leinen M, Prospero JM, Arnold E, Blank M (1994) Mineralogy of aeolian dust reaching the North Pacific Ocean: 1. Sampling and analysis. J Geophys Res 99:21017. https://doi.org/10.1029/94JD01735

Li D, Fu Y, Liu Q, Reinfelder JR, Hollings P, Sun X, Tan C, Dong Y, Ma W (2020) High-resolution LA-ICP-MS mapping of deep-sea polymetallic micronodules and its implications on element mobility. Gondwana Res 81:461-474. https://doi.org/10.1016/j.gr.2019.12.009

Matthews KJ, Maloney KT, Zahirovic S, Williams SE, Seton M, Müller RD (2016) Global plate boundary evolution and kinematics since the late Paleozoic. Global Planet Change 146:226-250. https://doi.org/10.1016/j.glopl acha.2016.10.002

Mewes K, Mogollón JM, Picard A, Rühlemann C, Kuhn T, Nöthen K, Kasten S (2014) Impact of depositional and biogeochemical processes on small scale variations in nodule abundance in the Clarion-Clipperton Fracture Zone. Deep Sea Res Part I. Oceanogr Res Pap 91:125-141. https://doi. org/10.1016/j.dsr.2014.06.001

Nielsen SG, Mar-Gerrison S, Gannoun A, LaRowe D, Klemm V, Halliday AN, Burton KW, Hein JR (2009) Thallium isotope evidence for a permanent increase in marine organic carbon export in the early Eocene. Earth Planet Sci Lett 278:297-307. https://doi.org/10.1016/j.epsl.2008.12.010 
Nozaki T, Ohta J, Noguchi T, Sato H, Ishikawa A, Takaya Y, Kimura Jl, Chang Q, Shimada K, Ishibashi J, Yasukawa K, Kimoto K, lijima K, Kato Y (2019) A Miocene impact ejecta layer in the pelagic Pacific Ocean. Sci Rep 9:1-9. https://doi.org/10.1038/s41598-019-52709-1

Ogg JG (2012) Geomagnetic polarity time scale. In: Gradstein FM, Ogg JG, Schmitz MM, Ogg GM (eds) The geologic time scale 2012. Elsevier B.V, The Netherlands, pp 85-113

Ohta J, Yasukawa K, Nozaki T, Takaya Y, Mimura K, Fujinaga K, Nakamura K, Usui Y, Kimura Jl, Chang Q, Kato Y (2020) Fish proliferation and rare-earth deposition by topographically induced upwelling at the late Eocene cooling event. Sci Rep 10:1-11. https://doi.org/10.1038/s41598-020-66835-8

Paquay FS, Ravizza GE, Dalai TK, Peucker-Ehrenbrink B (2008) Determining chondritic impactor size from the marine osmium isotope record. Science. 320(5873): 214-218. https://doi.org/10.1126/science.1152860

Pegram WJ, Turekian KK (1999) The osmium isotopic composition change of Cenozoic sea water as inferred from a deep-sea core corrected for meteoritic contributions. Geochim Cosmochim Acta 63:4053-4058. https ://doi.org/10.1016/s0016-7037(99)00308-7

Peucker-Ehrenbrink B, Ravizza G (2000) The marine osmium isotope record. Terra Nova 12:205-219. https://doi.org/10.1046/j.1365-3121.2000.00295.x

Peucker-Ehrenbrink B, Ravizza GE (2012) Osmium isotope stratigraphy. In: Gradstein FM, Ogg JG, Schmitz MD, Ogg HJ, Gabi M (eds) The geologic time scale 2012. Elsevier B.V, The Netherlands, pp 145-166

Ravizza G, Peucker-Ehrenbrink B (2003) The marine 1870 s/1880s record of the Eocene-Oligocene transition: the interplay of weathering and glaciation. Earth Planet Sci Lett 210:151-165. https://doi.org/10.1016/S0012 $-821 \times(03) 00137-7$

Rea DK, Janecek TR (1981) Late cretaceous history of eolian deposition in the mid-pacific mountains, central North Pacific Ocean. Palaeogeogr Palaeoclimatol Palaeoecol 36:55-67. https://doi.org/10.1016/00310182(81)90048-1

Rutledge AK, Roberts JA, Orsi TH, Bryant WR, Kotilainen AT (1995) 35. Geotechnical properties and consolidation characteristics of north Pacific sediments, Sites 881, 883, and 885/886. In: Rea DK, Basov IA, Scholl IA, Allan JF, et al. (eds) Proceedings of the Ocean Drilling Program, 145 Scientific Results. Ocean Drilling Program, College Station, pp. 525-546

Shimono T, Yamazaki T (2016) Environmental rock-magnetism of Cenozoic red clay in the South Pacific Gyre. Geochem Geophys Geosyst 17:1296-1311. https://doi.org/10.1002/2015GC006062

Shirey SB, Walker RJ (1995) Carius tube digestion for low-blank rheniumosmium analysis. Anal Chem 67:2136-2141. https://doi.org/10.1021/ ac00109a036

Stevens RL (1991) Grain-size distribution of quartz and feldspar extracts and implications for flocculation processes. Geo-Marine Lett 11:162-165. https://doi.org/10.1007/BF02431004

Syers JK, Chapman SL, Jackson ML, Rex RW, Clayton RN (1968) Quartz isolation from rocks, sediments and soils for determination of oxygen isotopes composition. Geochim Cosmochim Acta 32:1022-1025. https://doi. org/10.1016/0016-7037(68)90067-7

Takaya Y, Yasukawa K, Kawasaki T, Fujinaga K, Ohta J, Usui Y, Nakamura K, Kimura J-I, Chang Q, Hamada M, Dodbiba G, Nozaki T, lijima K, Morisawa T, Kuwahara T, Ishida Y, Ichimura T, Kitazume M, Fujita T, Kato Y (2018) The tremendous potential of deep-sea mud as a source of rare-earth elements. Sci Rep 8:5763. https://doi.org/10.1038/s41598-018-23948-5

Tanaka E, Nakamura K, Yasukawa K, Mimura K, Fujinaga K, lijima K, Nozaki T, Kato Y (2020) Chemostratigraphy of deep-sea sediments in the western North Pacific Ocean: implications for genesis of mud highly enriched in rare-earth elements and yttrium. Ore Geol Rev 119:103392. https://doi. org/10.1016/j.oregeorev.2020.103392
Turekian KK, Pegram WJ (1997) Os isotope record in a Cenozoic Deep-Sea core: its relation to global tectonics and climate. In: Ruddiman W (ed) Tectonic uplift and climate change. Springer, Boston, pp 383-397

Uramoto G-I, Morono Y, Tomioka N, Wakaki S, Nakada R, Wagai R, Uesugi K, Takeuchi A, Hoshino M, Suzuki Y, Shiraishi F, Mitsunobu S, Suga H, Takeichi Y, Takahashi Y, Inagaki F (2019) Significant contribution of subseafloor microparticles to the global manganese budget. Nat Commun 10:400. https://doi.org/10.1038/s41467-019-08347-2

Usui Y, Yamazaki T, Saitoh M (2017) Changing abundance of magnetofossil morphologies in pelagic red clay around Minamitorishima, Western North Pacific. Geochem Geophys Geosystems 18:4558-4572. https://doi. org/10.1002/2017GC007127

Usui Y, Shimono T, Yamazaki T (2018) Rock magnetism of quartz and feldspars chemically separated from pelagic red clay: a new approach to provenance study. Earth Planets Space 70:153. https://doi.org/10.1186/s4062 3-018-0918-1

Usui Y, Yamazaki T, Oka T, Kumagai Y (2019) Inverse magnetic susceptibility fabrics in pelagic sediment: implications for magnetofossil abundance and alignment. J Geophys Res Solid Earth. https://doi.org/10.1029/2019J B018128

Wegorzewski AV, Kuhn T (2014) The influence of suboxic diagenesis on the formation of manganese nodules in the Clarion Clipperton nodule belt of the Pacific Ocean. Mar Geol 357:123-138. https://doi.org/10.1016/j.marge 0.2014 .07 .004

Wessel P, Smith WHF, Scharroo R, Luis J, Wobbe F (2013) Generic mapping tools: improved version released. EOS Trans AGU 94(45):409-410. https:// doi.org/10.1002/2013EO450001

Yamazaki T (2009) Environmental magnetism of Pleistocene sediments in the North Pacific and Ontong-Java Plateau: temporal variations of detrital and biogenic components. Geochem Geophys Geosyst 10:Q07Z04. https:// doi.org/10.1029/2009GC002413

Yamazaki T, Shimono T (2013) Abundant bacterial magnetite occurrence in oxic red clay. Geology 41:1191-1194. https://doi.org/10.1130/G34782.1

Yamazaki T, Fu W, Shimono T, Usui Y (2020) Unmixing biogenic and terrigenous magnetic mineral components in red clay of the Pacific Ocean using principal component analyses of first-order reversal curve diagrams and paleoenvironmental implications. Earth Planets Space 72:120. https://doi. org/10.1186/s40623-020-01248-5

Yasukawa K, Nakamura K, Fujinaga K, Iwamori H, Kato Y (2016) Tracking the spatiotemporal variations of statistically independent components involving enrichment of rare-earth elements in deep-sea sediments. Sci Rep 6:1-12. https://doi.org/10.1038/srep29603

Yasukawa K, Ohta J, Miyazaki T, Vaglarov BS, Chang Q, Ueki K, Toyama C, Kimura I, Tanaka E, Nakamura K, Fujinaga K, lijima K, Iwamori H, Kato Y (2019) Statistic and isotopic characterization of deep-sea sediments in the western North Pacific Ocean: implications for genesis of the sediment extremely enriched in rare earth elements. Geochem Geophys Geosyst 20:3402-3430. https://doi.org/10.1029/2019GC008214

Zhang W, Chen J, Ji J, Li G (2016) Evolving flux of Asian dust in the North Pacific Ocean since the late Oligocene. Aeolian Res 23:11-20. https://doi. org/10.1016/J.AEOLIA.2016.09.004

\section{Publisher's Note}

Springer Nature remains neutral with regard to jurisdictional claims in published maps and institutional affiliations. 